\title{
VISUALIDADE, MEMÓRIA E SONHO NAS DRAMATURGIAS DE PHILIPPE GENTY
}

\author{
Flávia Ruchdeschel D'ávila1 \\ Wagner Francisco Cintra Araujo²
}

Resumo: Philippe Genty é um dramaturgo francês que começou a atuar na década de 60, como marionetista. Mundialmente conhecido por seus espetáculos e por séries televisivas concebidas entre os anos 70 e 80, com o passar do tempo o seu trabalho como marionetista evoluiu para um tipo de teatro que o artista denomina como teatro visual. O teatro visual é um conceito surgido na década de 80 na Europa e, no caso de Philippe Genty, à guisa de uma definição prévia desse termo, podemos afirmar que a marionete deixou de ser o principal elemento de seus espetáculos e que todos os elementos da encenação, inclusive o elemento humano, passaram a contribuir significativamente para a construção das suas novas dramaturgias. Nesses espetáculos o texto - entendido aqui como aquele texto que o ator fala em cena tem a mesma ou menor importância que os outros elementos expressivos - como a música, a dança, a luz, a matéria, os objetos, os atuantes, o espaço. Assim como a visualidade, a memória e o sonho podem ser considerados materiais expressivos que desempenham significativo papel nas dramaturgias de Philippe Genty e, é acerca desses tópicos, que discorreremos neste artigo.

Palavras-chave: Teatro; Memória; Sonho; Dramaturgia; Visualidade.

\footnotetext{
${ }^{1}$ Artes Cênicas/Universidade Estadual Paulista Júlio de Mesquita Filho - UNESP/Instituto de Artes, Brasil. E-mail: flaviaconta@gmail.com.

2 Doutorado em Artes/Universidade Estadual Paulista Júlio de Mesquita Filho - UNESP/Instituto de Artes, Brasil. E-mail: wagcintra@terra.com.br.
} 